Book Review

\title{
Expert Frames: Scientific and Policy Practices of Roma Classification. By Mihai Surdu. Budapest: Central European University Press, 2015, 267 pp., ISBN 978-963-386-113-4.
}

\author{
Yaron Matras \\ School of Arts, Languages and Cultures, University of Manchester, Manchester, M13 9PL, UK; \\ E-Mail: yaron.matras@manchester.ac.uk
}

Submitted: 10 August 2015 | Accepted: 11 August 2015 | Published: 29 September 2015

\begin{abstract}
The book offers a critique of current political and academic discourse on Roma, and calls for a "de-politicisation" of Romani ethnicity. While the critique of various disciplines' approaches to Roma is pertinent, the book fails to acknowledge the solid linguistic evidence for the Indian origin of the Roma.
\end{abstract}

\section{Keywords}

ethnicity; expert discourse; Indian origin; Roma

\section{Issue}

This book review is part of the special issue "Talking about Roma: Implications for Social Inclusion", edited by Dr. Eben Friedman (Independent Consultant and Senior Non-resident Research Associate, European Centre for Minority Issues, Germany).

(C) 2015 by the author; licensee Cogitatio (Lisbon, Portugal). This article is licensed under a Creative Commons Attribution 4.0 International License (CC BY).

The assertion that "policy research targeting Roma may do more harm than good" (p. 7) probably best summarises Mihai Surdu's motivation to engage in a critical assessment of expert and academic discourse on Roma. Surdu's argument is that European institutions have formed a bureaucratic apparatus in order to address "Roma" as a social problem (p. 3). According to the author this approach is accompanied by expert narratives, which in turn serve to strengthen the ideology that guides institutional policy. Surdu seeks to critically examine the "classifiers" that make up the target population of these policy interventions and the narratives that accompany them.

Surdu correctly identifies "Roma" as the selfappellation of a particular group as well as a term that has more recently taken on the function of a politically correct placeholder for "Gypsy", which in turn denotes a much wider and more vaguely defined target group consisting of diverse populations (for a similar view see Matras, 2005, 2013). But he argues that Roma were not an ethnic group until their status in Europe became politicised. Inspired by the works of Mayall (2004), Lu- cassen (1998), Willems (1997), and van Baar (2009), Surdu proposes that Roma ethnicity is the product of political institutions, an activist elite, and the arguments provided by academics.

Laying out his theoretical perspective in Chapter 2 (p. 41ff.), Surdu relies on Weber (1956[1978]), Bourdieu (1991), and Brubaker (2004) in arguing that (any) ethnicity is primarily a product of mass mobilisation by political entrepreneurs in search of symbolic resources for themselves and their supporters (p. 50). As part of this enterprise, political entrepreneurs cultivate myths of origins, a process which in turn offers them political dividends.

Chapter 3 (p. $71 \mathrm{ff}$.) offers a casual discussion of historical definitions of Roma across institutional practices and academic disciplines, with brief references to police categorisations in the $18^{\text {th }}$ and $19^{\text {th }}$ centuries, race biology, anthropology, and genetics. This is supplemented later by Chapter 7 (p. 219 ff.), an excursion devoted to visual representation. Here the author comments on the choice of images that accompany reports and policy documents. At first I wondered about the purpose of this short, non-exhaustive survey; but then I 
was reminded of the poignant choice of imagery that recently accompanied a joint statement by George Soros and Council of Europe Secretary General Thorbjørn Jagland (in March 2015): The web comment announcing plans for a European Roma Institute appeared next to a picture of young Romani violinists and guitarists, clearly seeking to connect with what a wider public might accept as a positive image of Roma.

Setting out to prove that Romani ethnicity is not an objective concept but a contextual construction, Surdu devotes Chapter 4 (p. 103 ff.) to contradictions in the way ethnic classifiers have been applied. Roma are associated at times with socio-economic descriptors, language, and self-ascriptions, but these descriptors often fail to overlap. Such conceptual contradictions lead to practical policy challenges: Since the definition of Roma is permeable, survey tools that are applied to Roma are porous, rendering quantitative data unreliable. The concluding remarks to this chapter (p. 194) critique current trends in expert discourse: On the one hand, there is reluctance across much of the academic community to accept ethnicity as an objective category. On the other hand, researchers complain that Roma are undercounted, implying that more precise counting is possible and that there is an objective measure for identifying Roma. Surdu flags this contradiction as arising from experts' self-interest in promoting organisations that seek to secure resources and funds for themselves, and which therefore need to frame a problem and to highlight its importance. I was reminded here of policy reports on Roma by a group at Salford University (see Matras, 2015, Matras, Leggio \& Steel, 2015).

Chapter 5 ( $p 151 \mathrm{ff}$.) is dedicated to the "Influences of Academic and Expert Discourse About Roma". Surdu draws a distinction between academics, who are affiliated with universities, and experts, whose work is published and disseminated by policy bodies such as OSCE, ERRC, OSI, the World Bank or the Council of Europe. The latter, he says, enjoy wider dissemination. (The distinction becomes blurred when academics assume the role of advocate-consultants paid by and arguing on behalf of NGOs, as in the case of the Salford group referred to above). As one of several case studies described in the following chapter, Surdu then discusses a World Bank report on Roma which claimed that Roma have an aversion to engaging with education and health care. He argues that this report contributed to framing a policy that makes Roma culture responsible for their precarious situation. He goes on to attribute the influence of Jean Pierre Liégeois to the fact that his work was published by the Council of Europe. Here Surdu might have mentioned the Council of Europe's "Romed" programmeits largest project on Roma, to which Liégeois served as consultant-which promotes the need for "mediation" and so implicitly the view that their culture leads Roma to disengage from public institutions. In fact Simhandl (2006), whom Surdu cites extensively, reminds her read- ers of essentialising statements in Liégeois's earlier work, such as "a Traveller is someone who remains detached from his surroundings" and "the Gypsy worldview emphasises the present moment".

Overall, Surdu's point is that institutions adopt expert statements and impose a narrative, which then perpetuates itself through repetition across a sector of institutions becoming a dominant policy narrative. But in his concluding remarks he entangles himself in a slight contradiction. Having started off by claiming that ethnicity is by definition a political enterprise, he concludes with a call to "de-politicise Roma ethnicity" ( $p$. 248). He even dismisses "Roma voices" as "just institutional views put forward about Roma". One wonders, then, what would be left at the end of such a process of "de-politicisation" and whether the ideal state of affairs would be one where any recognition of Roma identity has vanished completely from the public discourse. Surdu lends authority to his claim that Romani ethnicity is "constructed" by citing political scientists who "agree on its political construction from above" ( $p$. 98). If that is the case then one wonders what the basis is for the construction of any ethnic identity-Irish, Palestinian, Kurdish, or Chinese-; and what justifies the effort to de-construct Romani ethnicity if it simply follows the pathway of any other politicised ethnic identity: Is it the absence of territorial claims, coupled with the range of lifestyle-oriented popular depictions of Gypsies as nomads, which leads Surdu to question Romani ethnicity with such vigour?

In fact, it seems that much of Surdu's scepticism with regard to Romani ethnicity is anchored not so much in the fundamental theoretical critique of the concept of ethnicity as such, but in his reluctance to accept the historical narrative of an Indian origin and the validity of the Romani language as an objective "classifier" of the vast majority of those who self-identify (in their own daily interactions, if not necessarily in formal census surveys) as "Roma". Inspired by the likes of Okely (1983), Lucassen (1998) and Willems (1997), Surdu speaks of the "supposed Indian origin" (p. 51). He argues in his concluding remarks (p. 245) that the deployment of the Indian connection portrays Roma as a non-European and therefore alien people, and that it thus reinforces the opposition between Roma and non-Roma (for a similar argument that claims that describing Romani practices amounts to "essentialising" and creates boundaries, see Tremlett's review of my book, 2014).

I do side with Surdu when he describes with some anguish how schools that he observed in Central and Eastern Europe have an "Indian corner" depicting India as the place in which Romani culture has its roots, and how they showcase Roma dancing and singing in front of delegations of visitors (p. 36). This reminds me of our own observations on the way Roma were exoticised in order to justify resources for third sector interventions in Britain (see Matras et al., 2015). The prob- 
lem is that Surdu does not seem to allow the possibility that there is a factual reality behind the depiction of Indian origins, and that a flat denial of Indian origins amounts to a suppression of science rather than a mere discursive critique.

It is telling that in his survey of academic disciplines Surdu devotes only one single paragraph to linguistics (p. 82). Here he misrepresents nineteenth century attempts to classify Romani dialects on the basis of loanwords as if they had key relevance to contemporary Romani linguistics; he falls into the conventional laymen trap by equating language with vocabulary (rather than the coherence of core vocabulary and grammatical inflections); and he ignores two centuries of scholarship that have proven beyond any doubt that the Romani language originates in India and that its presence in Europe therefore testifies to a historical migration of a population from India to Europe. In describing this scientific argument as an attempt to exoticise Gypsies (p. 91) Surdu follows in the footsteps of Okely (1983), Willems (1997), Lucassen (1998), and others in challenging the epistemological legitimacy of historical linguistics rather than engaging with its arguments and the evidence on which they are based.

Arguably, denial of unique and separate Romani traditions, linguistic or other, whatever their historical origins, amounts to an assimilationist approach. The challenge facing European policy is not how to erase cultural differences, but how to ensure that Roma are free to maintain whatever unique attributes and traditions they choose without suffering discrimination as a result. Surdu's critique of the self-serving trends toward essentialising and segregation is welcome and inspiring; but in denying that there is anything at all in Romani identity that is tangible, he seems to be taking things just one step too far.

\section{Conflict of Interests}

The author declares no conflict of interests.

\section{References}

Bourdieu, P. (1991). Language and symbolic power. Cambridge: Polity Press.

Brubaker, R. (2004). Ethnicity without groups. Cam- bridge: Harvard University Press.

Lucassen, L. (1998). "Harmful tramps": Police professionalization and Gypsies in Germany, 1700-1945. In L. Lucassen, W. Willems, \& A.-M. Cottaar (Eds.), Gypsies and other itinerant groups: A socio-historical approach (pp. 74-93). New York: St. Martin's Press.

Matras, Y. (2005). The role of language in mystifying and de-mystifying Gypsy identity. In N. Saul \& S. Tebbut (Eds.), The role of the Romanies (pp. 53-78). Liverpool: University of Liverpool Press.

Matras, Y. (2013). Scholarship and the politics of Romani identity: Strategic and conceptual issues. European Yearbook of Minority Issues, 10, 209-245.

Matras, Y. (2015). Use and misuse of data on Roma: A comment on the Salford study on Roma migrants. Zeitschrift für internationale Bildungsforschung und Entwicklungspädagogik, 38, 29-30.

Matras, Y., Leggio, D. V., \& Steel, M. (2015). “Roma education" as a lucrative niche: ildeologies and representations. Zeitschrift für internationale Bildungsforschung und Entwicklungspädagogik, 38, 11-17.

Mayall, D. (2004). Gypsy identities 1500-2000. From Egipcyans and Moon-men to the ethnic Romany. London and New York: Routledge.

Okely, J. (1983). The Traveller-Gypsies. Cambridge: Cambridge University Press.

Simhandl, K. (2006). "Western Gypsies and Travellers". "Eastern Roma": The creation of political objects by the institutions of the European Union. Nations and Nationalism, 12, 97-115.

Tremlett, A. (2014). Review of Y. Matras, "I Met Lucky People". The Story of the Romani Gypsies. Times Higher Education, 6 March 2014.

van Baar, H. (2009). Contesting neo-liberal practices in Central and Eastern Europe: Romani minority governance between activation and activism. Retrieved from http://www.researchgate.net/publication/2288 94746_Contesting_Neo-liberal_Practices_in_Central _and_Eastern_Europe_Romani_Minority_Governanc e_Between_Activation_and_Activism

Weber, M. (1956[1978]). Economy and society. An outline of interpretative sociology. Berkeley: University of California Press.

Willems, W. (1997). In search of the true Gypsy: From enlightenment to final solution. London: Frank Cass.

\section{About the Author}

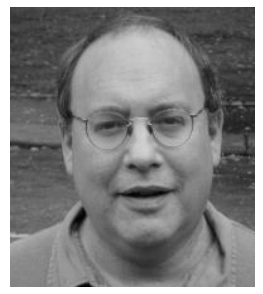

\section{Dr. Yaron Matras}

Yaron Matras is Professor of Linguistics at the University of Manchester, and author of The Romani Gypsies (Harvard University Press, 2015). He is editor of the journal Romani Studies, and Coordinator of MigRom, a European research consortium on Roma migration. 